\title{
Autumn ichthyoplankton assemblage in the Yangtze Estuary shaped by environmental factors
}

Hui Zhang, Weiwei Xian, Shude Liu

This study investigated the response of the ichthyoplankton community to environmental changes in the Yangtze Estuary using canonical correspondence analysis . Ichthyoplankton community and environmental data were recorded during autumns in 1998, 2000, 2002, 2003, 2004, 2007 and 2009. Among the ichthyoplankton, the dominant larval and juvenile families were the Engraulidae, Gobiidae and Salangidae, and the most common eggs were from Trichiurus lepturus. The ichthyoplankton was identified via canonical correspondence analysis to three assemblages: an estuary assemblage dominated by Chaeturichthys stigmatias, a coastal assemblage dominated by Engraulis japonicus and Stolephorus commersonii, and an offshore assemblage dominated by Trichiurus lepturus. Regarding environmental factors in the Yangtze Estuary, suspended matter and surface seawater salinity were the main factors influencing the distributions of the different assemblages, while sediment from the Yangtze River during the rainy season and chlorophyll a were the principle drivers of the annual variances in the distribution of ichthyoplankton assemblages. Our aims in the present study are to provide detailed characterizations of the ichthyoplankton assemblage in autumns, examine the long-term dynamics of autumn ichthyoplankton assemblages, and evaluate the influence of environmental factors on the spatial distribution and inter-annual variations of ichthyoplankton assemblages associated with the Yangtze Estuary. 


\section{Title page}

2

3 Title

4 Autumn ichthyoplankton assemblage in the Yangtze Estuary shaped by

5 environmental factor

6

\section{Authors}

8 Hui Zhang, Weiwei Xian* and Shude Liu

9 Key Laboratory of Marine Ecology and Environment Sciences, Institute of

10 Oceanology, Chinese Academy of Sciences, Qingdao, 266071, China

\section{* Corresponding author}

Weiwei XIAN

E-mail: wwxian@qdio.ac.cn

Tel \& Fax: +86-532-82898594 
12 Abstract: This study investigated the response of the ichthyoplankton community to 13 environmental changes in the Yangtze Estuary using canonical correspondence analysis. 14 Ichthyoplankton community and environmental data were recorded during autumns in 1998, $152000,2002,2003,2004,2007$ and 2009. Among the ichthyoplankton, the dominant larval and 16 juvenile families were the Engraulidae, Gobiidae and Salangidae, and the most common eggs 17 were from Trichiurus lepturus. The ichthyoplankton was identified via canonical correspondence 18 analysis to three assemblages: an estuary assemblage dominated by Chaeturichthys stigmatias, a 19 coastal assemblage dominated by Engraulis japonicus and Stolephorus commersonii, and an 20 offshore assemblage dominated by Trichiurus lepturus. Regarding environmental factors in the 21 Yangtze Estuary, suspended matter and surface seawater salinity were the main factors 22 influencing the distributions of the different assemblages, while sediment from the Yangtze 23 River during the rainy season and chlorophyll $a$ were the principle drivers of the annual 24 variances in the distribution of ichthyoplankton assemblages. Our aims in the present study are to 25 provide detailed characterizations of the ichthyoplankton assemblage in autumns, examine the long-term dynamics of autumn ichthyoplankton assemblages, and evaluate the influence of 27 environmental factors on the spatial distribution and inter-annual variations of ichthyoplankton 28 assemblages associated with the Yangtze Estuary. 


\section{Introduction}

32 The Yangtze Estuary, an area of complex and varied environmental conditions, is the link 33 between the Yangtze River and East China Sea (Luo \& Shen 1994). Sea currents in this area are 34 impacted by freshwater input from the Yangtze River, the Huanghai Cold Water Column and the 35 Taiwan Strait Current. Large volumes of nutrients are carried by the river; therefore, the Yangtze 36 Estuary has high primary production and rich food resources (Luo \& Shen 1994). Various fish 37 species feed, fatten and reproduce in this area. In recent years, with economic development and 38 increasing population, resource and environmental exploitation has increased, resulting in 39 enormous pressure on the ecology of the Yangtze Estuary and adjacent waters. Such 40 environmental changes will inevitably affect the survival of some species and, hence, the 41 structure of biological communities in the Yangtze Estuary.

42 Ichthyoplankton, including fish eggs, larvae and juveniles, is the basis for the sustainable 43 utilization of fishery resources (Miller and Kendall 2009; Zhang et al., 2015), with survival 44 directly influencing recruitment. Because of absent or weak independent swimming capabilities 45 and a drifting nature, ichthyoplankton are poorly adapted to changing environmental conditions. 46 Thus, ichthyoplankton are sensitive and susceptible to environmental changes and, therefore, a 47 suitable indicator of variations in the ecological environment (Boeing and Duffy-Anderson 2008). 48 The ichthyoplankton assemblages in estuaries are complex both in species composition and 49 distribution. Studies show that the organization of ichthyoplankton in estuarine systems is 50 influenced by the interactive effects of a multitude of biotic and abiotic processes. Biological 51 factors include the location, timing and manners of spawning, larval life history, larval behavior, 52 rates of predation, and feeding (Leis 1991; Azeiteiro 2006). Physical factors include salinity 53 (Whitfield 1999), temperature (Blaxter 1992), turbidity (Islam et al. 2006), dissolved oxygen 54 (Rakocinski et al. 1996), depth (Wantiez et al. 1996), river flow (Faria et al. 2006), sediment 55 characteristics and hydrographic events such as currents, winds, eddies, upwelling and 56 stratification of the water column (Gray 1993). A study of the assemblage structure of the 
57 ichthyoplankton community is necessary for the sustainable utilization of fishery resources, 58 while knowledge of its dynamic characteristics can be utilized to monitor the health of an aquatic 59 environment.

60 To date, investigations into ichthyoplankton communities in Yangtze Estuary have mainly concentrated on species composition, fauna distribution and seasonal variations (i.e. Yang et al., 1990), discussions on the relationship between the ichthyoplankton community and environmental factors (Jiang et al., 2006; Liu et al., 2008), or long term dynamics of spring 64 ichthyoplankton assemblages (Zhang et al., 2015). Fish reproduce in the Yangtze Estuary 65 throughout the year, and fishery resources are most abundant in autumn. However, there are few 66 studies on the Yangtze Estuary as a breeding/nursery area for fish and the factors affecting 67 survival/recruitment in autumns. This study investigated the impact of environmental factors on 68 the ichthyoplankton community at seven autumns in 1998, 2000, 2002, 2003, 2004, 2007 and 2009 in the Yangtze Estuary and the drivers of changes in the community using a communityecology analytical method. The aim was to provide detailed characterizations of the ichthyoplankton assemblage in autumns, reveal the seasonal difference between spring and autumn, and evaluate the influence of human activities on the recruitment of fishery resources.

\section{Materials and methods}

\section{Study area and sample collection}

76 Forty stations were established in the Yangtze Estuary $\left(30^{\circ} 45^{\prime}-32^{\circ} 00^{\prime} \mathrm{N}, 121^{\circ} 00^{\prime}-123^{\circ} 20^{\prime} \mathrm{E}\right)$

77 during seven autumns (11/1998, 11/2000, 11/2002, 11/2003, 11/2004, 11/2007 and 11/2009), 78 including five stations within the river and all others outside the river mouth (Fig. 1).

79 Biological and oceanographic data were collected during seven fishery-evaluation cruises in 80 seven autumns. Biological samples were collected by surface towing a larva net (0.8-m mouth 81 diameter, 2.8-m length, 0.505-mm mesh at the body, and 0.505-mm mesh at the cod end) 82 equipped with a flow meter. At each station, the net was towed at a depth of $\sim 0.5 \mathrm{~m}$ from the 
83 surface for 10 min against the tidal flow, at a towing speed of approximately $2-3$ knots. After

84 completion of each tow, the nets were washed and the samples fixed and preserved in $5 \%$ 85 buffered formaldehyde-seawater solution.

86 Geographical locations of sampling stations were provided by GPS, version Magellan 315.

87 At each station, environmental variables, including depth (D), salinity (S), temperature (T), 88 transparency (Trans), dissolved oxygen (DO), $\mathrm{pH}$, total phosphorus (TP), total nitrogen (TN), 89 total suspended matter (TSM), chemical oxygen demand (COD), and chlorophyll $a$ (Chla), were 90 determined according to the GB/T 12763-2007, Specification for Marine Monitoring (State

91 Oceanic Administration of China). Because changes in freshwater flow into an estuary and 92 adjacent areas affect nutrient levels, with consequences for primary productivity and associated 93 trophic chains (Morais et al., 2009) and the above influences are always lagging behind. But as 94 we could not get the data on freshwater flow directly, in the present study, we choose the instead 95 factor, total sediment (TSedi) entering the estuary from the Yangtze River during the rainy 96 season brought by freshwater flow, to do the analysis. The data on TSedi were provided by the 97 Datong monitoring stations in the Changjiang Sediment Bulletin (unpublished data).

\section{Data analysis}

100 Ichthyoplankton were identified in the laboratory to the lowest possible taxonomic level. 101 Numerical density for each species was standardized to catch per unit effort (CPUE) as 102 abundance per 10 tow units.

103 The dominant species were determined using the Index of Relative Importance (IRI) 104 developed by Zhu et al. (2002):

$$
\mathrm{IRI}=\mathrm{N} * 100 \% * \mathrm{~F} * 100 \%
$$

$106 \mathrm{~N}^{*} 100 \%$ and $\mathrm{F}^{*} 100 \%$ are the relative abundance and frequency of occurrence, respectively. 107 The IRI of the dominant species should be greater than 100.

108 The ichthyoplankton assemblage structure and the relationship of the structure to 
109 environmental factors was analyzed via canonical correspondence analysis (CCA), which is 110 utilized to visualize and describe the relationship between fish species and environmental 111 variables (CANOCO Software, Version 4.5). Only species that occurred in $>1 \%$ of the catches, 112 based on all species, were included in the analysis. Species abundance data were $\log 10(x+1)$

113 transformed to reduce the dominant effect of some species (Clarke and Warwick, 2001). A total 114 of 33 species and 11 environmental factors were selected for CCA, using the following steps: (1) 115 discard environmental variables with an inflation factor $>20$ following each CCA iteration; (2) 116 test marginal effects and unique effects of every environmental variable; (3) assess the 117 contribution and significance of each variable using inter-set correlations between the CCA axes 118 and environmental factors, as well as Monte Carlo permutation $(P<0.05)$ analysis simulation and 119 the forward selection option within CANOCO (CANOCO Software, Version 4.5, ter Braak, 120 1987).

121

\section{Results}

123 A total of 969 ichthyoplankton constituting 33 species from 19 families and 10 orders were 124 collected during the seven sampling autumns in the Yangtze Estuary, including 226 fish eggs and 125743 larvae and juveniles (Table 1). Perciformes was the most abundant fish species, while 126 species from the Order Clupeiformes were the second most common. The dominant larval and 127 juvenile species were from the Engraulidae, Gobiidae and Salangidae families. The most 128 abundant eggs where those of the largehead hairtail, Trichiurus lepturus (Table 2). Raw data of 129 the present work could be download as the supplements.

130 Results of species-station and environment-station matrix analysis showed that the sum of all 131 canonical eigenvalues was 2.844 (Table 3). The cumulative percentage variance of species 132 totaled $17.5 \%$ and the cumulative percentage variance of species-environment was $72.2 \%$. 133 Eigenvalues of the first four axes was 0.696 (CCA1), 0.549 (CCA2), 0.419 (CCA3) and 0.389 134 (CCA4); the eigenvalues of the first two axes were moderately high. The correlation between the 
135 first two axes and environmental factors was the highest with correlation coefficients of 0.884 136 and 0.788 , respectively. The first two CCA axes explained $10.6 \%$ of the cumulative percentage 137 variance in species and $43.8 \%$ of cumulative percentage variance in species-environment (Fig. 138 2).

139 Through Monte Carlo tests of $F$-ratios $(P<0.05)$, TSM, S, TSedi from the Yangtze River 140 during the rainy season, Chla and $\mathrm{PH}$ of surface seawater were the most active environmental 141 parameters affecting ichthyoplankton. Total variation due to TSM and TSedi was higher than 142 other environmental factors. The patterns of D, TN, TP, TSM and S were highly correlated with 143 the first CCA axis, and this CCA1 axis represented a spatial gradient from the Yangtze River to 144 the sea. There was a high correlation between the second axis and TSedi, i.e. sediment from the 145 Yangtze River during the rainy season, and Chla; the CCA2 axis represented a temporal gradient 146 (Table 4).

147 TSM was negatively correlated with S, D and transparency (Trans), representing a decrease in 148 TSM from the river to the Offshore with increasing salinity, depth and transparency. There was a 149 positive correlation between TSedi and Chla, both impacting on changes in the annual 150 ichthyoplankton assemblage. There were combined effects of environmental factors in the CCA 151 biplot of ichthyoplankton species. The resulting hierarchical classification yielded both species 152 and station groups.

153 Three species groups were revealed by CCA (Table 1, Fig. 2):

154 Estuary assemblage: This group included four species (Chaeturichthys stigmatias, Salanx 155 prognathous, Pseudolaubuca engraulis and Pseudorasbora parva), distributed in an area of low 156 salinity and high suspended matter;

157 Coastal assemblage: This group included seven species (such as Stolephorus commersonii, 158 Engraulis japonicus, Salanx ariskensis), distributed in brackish water;

159 Offshore assemblage: This group included seven species (such as Trichiurus lepturus, Thryssa 160 kammalensis, Harpadon nehereus), distributed on top-left of the CCA biplot and correlated with 
161 salinity.

162 Three station areas were also revealed by CCA (Table 1, Fig. 3A and Fig. 3B):

163 I Estuary area consisting of five sites: 35, 36, 37, 38 and 39, distributed in the river system. In

164 this group, Chaeturichthys stigmatias (57.48\%) was the most abundant species, followed by 165 Salanx prognathous (22.05\%). Salinity in this area was $2.34 \pm 1.1 \%$, and the total suspended 166 matter was $121.66 \pm 61.54 \mathrm{mg} / \mathrm{L}$.

167 II Coastal area consisting of 16 sites: 9-11, 15-18, 21-24, 28-31 and 40, distributed in water 168 near the mouth of the Yangtze Estuary. The dominant species in this group included Salanx 169 prognathous (29.81\%), Stolephorus commersonii (23.40\%) and Engraulis japonicus (20.06\%).

170 Salinity in this area was $19.41 \pm 8.17 \%$ and the total suspended matter were $134.77 \pm 240.10 \mathrm{mg} / \mathrm{L}$, 171 the highest of three groups.

172 III Offshore area consisting of 19 sites: 1-8, 12-14, 19, 20, 25-27 and 32-34, located in 173 offshore areas outside the Yangtze Estuary. Trichiurus lepturus $(58.90 \%)$ and Engraulis 174 japonicus $(10.68 \%)$ were the dominant species. Salinity in this area was $19.41 \pm 8.17 \%$ o (the 175 highest of three groups), and the total suspended matter was $7.78 \pm 13.99 \mathrm{mg} / \mathrm{L}$ (the lowest of 176 three groups).

177 In all, environmental conditions were significantly different among the three stations groups, 178 and the distributions of ichthyoplankton varied with environmental factors from the estuary to 179 the offshore area.

180

\section{Discussion}

182 As a result of the interaction between biological and abiotic factors, in this study, coastal and 183 offshore ichthyoplankton were dominant in the Yangtze Estuary during the November sampling 184 periods. Compared with the characteristics of the ichthyoplankton assemblage within the 185 Yangtze Estuary in springs (Zhang et al, 2015), species composition differed in autumns and the 186 species within the three groups were also different. The S. commersonii assemblage group 
187 remained unchanged compared to the results in springs, although the seawater temperature

188 within the estuary water may have changed between springs and autumns (Zhang et al., 2015).

189 Moreover, formation of the ichthyoplankton assemblage and maintenance of the community 190 structure was impacted by the spawning patterns and distribution of fish species (Duffy191 Anderson et al., 2006; Rodriguez, 2008), but the majority of fish species do not spawn in autumn.

192

193 Seasonal patterns of abundance of ichthyoplankton are mainly linked to reproductive 194 strategies of adult population and phases of their life cycles, which, in turn are often associated 195 with oceanographic and meteorological features (Hernández-Miranda et al., 2003). Most of the 196 species collected in Yangtze Estuary spawned in spring or early in the summer and both the 197 species and the amount of ichthyoplankton were decreased in autumn. The present study and 198 other studies supported the above point (i.e. Yang et al., 1990; Jiang \& Shen, 2006; Yu and Xian, 199 2009). That is one of the reasons that there are significant differences in ichthyoplankton 200 assemblages between spring and autumn.

201 The ability of larval and juvenile fish to survive the pelagic phase and migrate to a suitable 202 adult habitat may be dependent on their ability to regulate their dispersal or migration (Muhling 203 \& Beckley, 2007); larvae of different species tend to co-occur as a result of parallels in their life 204 histories (Gray \& Miskiewicz, 2000). Duffy-Anderson et al. (2006) found that exposure to 205 similar hydrographic processes and convergence with a similar resource can all lead to discrete 206 groupings of co-occurring larval fish species. The ichthyoplankton assemblage was grouped in 207 accordance with suspended matter and surface seawater salinity within the Yangtze Estuary in 208 autumn, and the difference in distribution within each group was the result of sediment from the 209 Yangtze River during the rainy season and chlorophyll $a$.

210 CCA analysis was utilized to reflect the correlations between community groups and 211 environmental factors. The ichthyoplankton assemblage was divided into three groups: an 212 estuary, coastal and Offshore assemblage. Compared with the ichthyoplankton assemblage 
213 pattern in spring after 2004 (Zhang et al., 2015), there were three groups in autumn and the

214 distribution of the coastal assemblage was significantly enlarged compared with the estuary or 215 offshore assemblage. Suspended matter and surface seawater salinity were the most important 216 environmental factors influencing the ichthyoplankton assemblage pattern. However, total 217 sediment from the Yangtze River during the rainy season and chlorophyll $a$ were the major 218 factors affecting changes in the annual ichthyoplankton assemblage. Other environmental factors, 219 such as temperature, nutrients, depth, dissolved oxygen and chemical oxygen demand, had no 220 significant impact on ichthyoplankton.

221 In estuaries, there are significant gradients in salinity and turbidity (Islam et al., 2006). The 222 spatial distribution in salinity was impacted by runoff, flow rate in the river, tidal intensity and 223 topographic conditions (Zhou et al., 2007). Salinity is the most important environmental 224 condition for estuarine organisms, influencing not only growth, development and reproduction of 225 ichthyoplankton but also the temporal and spatial distribution of larval fish assemblages (Zhang 226 et al., 2015). Fish species, as well as fish eggs and larvae, differ in their ability to adapt to 227 salinity. Offshore, low-salinity seawater contributed to reproduction and egg hatching in fish 228 species, while the salinity and temperature range to which larvae and juveniles were adapted was 229 wider than that for fish eggs (Jiang et al., 2006).

230 The salinity was negatively correlated with suspended matter (Fig. 3), which was in agreement 231 with other research results from the Chikugo Estuary (Islam et al., 2006). This is an important 232 characteristic of estuarine ecosystems. Salinity gradually increases from the river to the sea while 233 suspended matter gradually decreases, resulting in an ecological gradient for salinity and 234 turbidity due to the inflow of fresh water carrying a large amount of sediment. In addition, 235 suspended matter was positive correlated with total phosphorus and total nitrogen. Seawater 236 areas with high suspended matter content had abundant nutrients and, therefore, large numbers of 237 food organisms. Such areas can result in increased predation rates of larval fish (Islam et al., 238 2006) but also provide shelter from predation (Barletta-Bergan, 2002). 
239 Freshwater inflow is the critical factor determining abiotic and biotic variability (Morais et al., 240 2009), and has an important impact on the distribution and abundance of ichthyoplankton within 241 an estuarine ecosystem (Faria et al. 2006). Changes in freshwater flow into an estuary and 242 adjacent areas affect nutrient levels, with consequences for primary productivity and associated 243 trophic chains (Morais et al., 2009). The CCA results demonstrate that total sediment entering 244 the Yangtze Estuary during the rainy season was one of the most important factors influencing 245 changes in the annual ichthyoplankton assemblage. River freshwater inflow and sediment levels 246 entering the Yangtze Estuary were impacted by large-scale, water-conservancy construction 247 projects in the upper reaches of the Yangtze River and rainfall, especially the construction of the 248 Three Gorges Dam. Some of the water, and thus sediment entering the Yangtze Estuary was 249 intercepted and the seasonal flow allocation of the Yangtze River was changed. In this study, no 250 correlation was found between sediment from the Yangtze River entering the sea during the 251 rainy season and suspended matter in the surface seawater, i.e. suspended matter in surface 252 seawater is not related to river flow or sediment entering the Yangtze Estuary during the whole 253 rainy season.

254 Chlorophyll $a$ also influenced changes in the annual ichthyoplankton assemblage, and was 255 positively correlated with sediment entering the Yangtze Estuary. Chlorophyll $a$ is a relative 256 accurate reflection of the standing crop of phytoplankton; the greater the phytoplankton biomass, 257 the higher the primary productivity (Whitfield 1999). There is a close relationship between 258 chlorophyll $a$ and nutrients from freshwater entering the estuary. When nutrient levels were high, 259 chlorophyll $a$ levels in the estuary were also high, and food resources, which are necessary for 260 the development and growth for larvae and juveniles, were abundant. Rich food resources also 261 increased survival and successful foraging rates. From the standpoint of trophodynamics, high 262 chlorophyll $a$ levels provided a food indicator for recruitment in the early life-stage of fish 263 species (Wan et al., 2002). Fig. 2 demonstrates that chlorophyll $a$ had a major impact on the 264 distribution of three freshwater fish, Stolephorus commersonii, Salanx ariskensis and Engraulis 
265 japonicus. Wan et al. (2002) also reported a close relationship between chlorophyll $a$ and the 266 distribution of eggs, larvae and juveniles of E. japonicus. Moreover, a study on the distribution 267 and variation in chlorophyll $a$ demonstrated the relationship between phytoplankton and the 268 environment and changes in environmental conditions (Ma et al., 2004).

$269 \mathrm{PH}$ is another important environmental factor influencing the distribution of an 270 ichthyoplankton assemblage. Vazzoler (1996) recorded a positive correlation between $\mathrm{PH}$ and 271 the density of some larval fish. Although it is unclear how $\mathrm{PH}$ affects reproductive processes, it 272 can induce spawning in some fish species. Baumgartner et al. (1997) noted that the preference of 273 some species for water with a weak acidic $\mathrm{pH}$ may be an adopted behavior. In addition to the 274 above-mentioned environmental factors, others, such as temperature, total phosphorus, total 275 nitrogen and chemical oxygen demand, can affect ichthyoplankton assemblages to some degree 276 but not significantly so. However, additional factors, such as ocean currents and 277 zooplankton/phytoplankton abundance, which were not investigated in this study and may affect 278 ichthyoplankton (Ignaciovilchis et al., 2009), require further detailed study.

279

280

\section{Conclusions}

281 There are three species groups and three station areas revealed by CCA based on the 282 biological and environmental data in the seven autumns in the Yangtze Estuary which was

283

284

285

286

287 288 ichthyoplankton.

289

290

\section{Acknowledgements} consistent to the results of the springs and other estuarine systems.

SPM and S were the most important environmental factors influencing the ichthyoplankton assemblage pattern. However, TSedi from the Yangtze River during the rainy season and Chla were the major factors affecting changes in the annual ichthyoplankton assemblage. Other environmental factors, such as $\mathrm{T}$, nutrients, $\mathrm{D}$, DO and COD, had no significant impact on

We are grateful to the editors and two anonymous reviewers for their constructive feedback and 
291 concerning on our work. We also thank Mr. Yan Qin for editing the figures.

292

293 Reference

294 Azeiteiro UM, Bacelar-Nicolau L, Resende P, Goncalves F, Pereira MJ.2006. Larval fish

295 distribution in shallow coastal waters off North Western Iberia (NE Atlantic). Estuarine,

296 Coastal and Shelf Science 69: 554-566.DOI: 10.1016/j.ecss.2006.05.023

297 Barletta-Bergan A. 2002. Structure and seasonal dynamics of larval fish in the Caeté River

298 Estuary in north Brazil. Estuarine, Coastal and Shelf Science, 54(2): 193-

299 206.DOI:10.1006/ecss.2001.0842

300 Baumgartner GK, Nakatani MC, Baumgartner MST. 1997. Some aspects of the ecology of fish

301 larva in the food plain of high Paraná River, Brazil. Rev Bras Zool, 14: 551-563.

302 DOI:10.1590/S0101-81751997000300005

303 Blaxter JHS.1992. The effect of temperature on larval fishes. Netherlands Journal of Zoology 42:

304 336-357. DOI: 10.1163/156854291X00379.

305 Boeing WJ, Duffy-Anderson JT. 2008. Ichthyoplankton dynamics and biodiversity in the Gulf of

306 Alaska: Responses to environmental change. Ecological Indicators, 8(3): 292-

307 302.DOI:10.1016/j.ecolind.2007.03.002

308 Clarke KR, Warwick RM. 2001. Changes in marine communities: an approach to statistical

309 analysis and interpretation. 2nd edition. Plymouth: Primer-e Ltd. 172 pp.

310 Duffy-Anderson JT, Busby MS, Mier KL, Deliyanides CM, Stabeno PJ. 2006. Spatial and

311 temporal patterns in summer ichthyoplankton assemblages on the eastern Bering Sea shelf

312 1996-2000. Fisheries Oceanography, 15(1): 80-94.DOI:10.1111/fog.120621

313 Faria A, Morais P, Chicharo, M. 2006. Ichthyoplankton dynamics in the Guadiana estuary and

314 adjacent coastal area, South-East Portugal. Estuarine, Coastal and Shelf Science, 70(1-2): 85-

315 97. DOI: $10.1016 /$ j.ecss.2006.05.032

316 Gray CA, Miskiewicz AG. 2000. Larval fish assemblages in south-east Australian coastal waters: 
317 seasonal and spatial structure. Estuarine, Coastal and Shelf Science, 50(4): 549318 570.DOI:10.1006/ecss.1999.0595

319 Gray CA. 1993. Horizontal and vertical trends in the distributions of larval fishes in coastal 320 waters off central New South Wales, Australia. Marine Biology 116: 649-666. DOI: $321 \quad 10.1007 / B F 00355483$.

322 Hernández-Miranda E, Palma AT, Ojeda FP, 2003. Larval fish assemblages in nearshore coastal 323 waters off central Chile: temporal and spatial patterns. Estuarine, Coastal and Shelf Science 56: 324 1075-1092. DOI:10.1016/S0272-7714(02)00308-6.

325 Ignaciovilchis L, Ballance L, Watson W. 2009. Temporal variability of neotenic ichthyoplankton 326 assemblages of the eastern Pacific warm pool: Can community structure be linked to climate 327 variability. Deep Sea Research Part I: Oceanographic Research Papers, 56(1): 125-140. 328 DOI:10.1016/j.dsr.2008.08.004

329 Islam MS, Hibino M, Tanaka M. 2006. Distribution and diets of larval and juvenile fishes: 330 Influence of salinity gradient and turbidity maximum in a temperate estuary in upper Ariake 331 Bay, Japan. Estuarine, Coastal and Shelf Science 68: 62-74.DOI: 10.1016/j.ecss.2006.01.010. 332 Jiang M, Shen XQ, Chen LF. 2006. Relationship between with abundance distribution of fish 333 eggs, larvae and environmental factors in the Changjiang Estuary and vicinity waters in spring. 334 Marine Environmental Science, 25(2): 37-39. (in Chinese with an English abstract)

335 Jiang M, Shen XQ. 2006. Abundance distributions of pelagic fish eggs and larva in the 336 Changjiang River estuary and vicinity waters in summer. Marine Sciences 30(6): 92-97. (in 337 Chinese with an English abstract)

338 Leis JM. 1991. The pelagic stage of reef fishes: the larval biology of coral reef fishes. In: 339 Sale, P. E (ed.) The ecology of fishes on coral reefs. Academic Press, New York, pp183-230 340 Liu SD, Xian WW, Liu D. 2008. Characters of ichthyoplankton assemblages in Yangtze Estuary 341 and adjacent waters in spring. Chinese Journal of Applied Ecology, 19(10): 2284-2292. DOI $342: 10.13287 / \mathrm{j} .1001-9332.2008 .0374$. (in Chinese with an English abstract) 
343 Luo BZ, Shen HT. 1994. The three gorges project and the ecological environment of Yangtze

344 Estuary. Science Press, Beijing, China. (in Chinese)

345 Ma ZQ, Zhou, Xue K, Wang NB. 2004. The relationship between the primary production and

346 fishery resources in the northern waters of Liaodong Bay. Fisheries Science, 23(4): 12-15. (in

347 Chinese with an English abstract)

348 Miller BS and Kendall AW.2009.Early Life History of Marine Fishes.University of California

349 Press.Berkeley and Los Angeles, California.

350 Morais P, Chícharo MA, Chícharo L. 2009. Changes in a temperate estuary during the filling of

351 the biggest European dam. Science of the Total Environment, 407(7): 2245-2259.

352 DOI:10.1016/j.scitotenv.2008.11.037

353 Muhling BA, Beckley LE. 2007. Seasonal variation in horizontal and vertical structure of larval

354 fish assemblages off south-western Australia, with implications for larval transport. Journal of

355 Plankton Research, 29(11): 967-983.DOI:10.1093/plankt/fbm072

356 Rakocinski CF, LyczkowskiShultz J, Richardson SL. 1996. Ichthyoplankton assemblage

357 structure in Mississippi sound as revealed by canonical correspondence analysis. Estuarine,

358 Coastal and Shelf Science 43:237-257. DOI: 10.1006/ecss.1996.0067.

359 Rodriguez JM. 2008. Temporal and cross-shelf distribution of ichthyoplankton in the central

360 Cantabrian Sea. Estuarine, Coastal and Shelf Science, 79(3): 496-506.

361 DOI:10.1016/j.ecss.2008.05.010.

362 State Oceanic Administration of China. GB/T 12763-2007, Specifications for oceanographic

363 survey. (in Chinese, attached as Supplemental Files)

364 ter Braak CJ F. 1987. Unimodal models to relate speices to environment. Wageningen, the 365 Netherlands:Agricultural Mathematics Group.

366 Vazzoler AEAM. 1996. Biologia da reprodução de peixes teleósteos: teoria e prática. Maringá, 367 Eduem, 169.

368 Wan RJ, Huang DJ, Zhan J, 2002. Abundance and distribution of eggs and larvae of engraulis 
369 japonicus in the northern part of East China Sea and the southern part of Yellow Sea and its

370 relationship with environmental conditions. Journal of Fisheries of China, 26(4): 321-330. (in

371 Chinese with an English abstract)

372 Wantiez L, Hamerlin-Vivien M, Kulbicki M. 1996. Spatialand temporal variation in a soft-

373 bottom fish assemblages in St.Vincent Bay, New Caledonia. Marine Biology 125:801-812.

374 DOI: $10.1007 / \mathrm{BF} 00349263$.

375 Whitfield AK.1999. Ichthyofaunal assemblages in estuaries: a South African case study. Reviews

376 in Fish Biology and Fisheries 9: 151-186. DOI: 10.1023/A:1008994405375.

377 Yang DL, Wu GZ, Sun JR. 1990. The investigation of pelagic eggs, larvae and juveniles of 378 fishes at the mouth of the Changjiang River and adjacent areas. Oceanologia et Limnologia 379 Sinica 21: 346-355. (in Chinese with an English abstract)

380 Yu HC, Xian WW, 2009. The environment effect on fish assemblage structure in waters adjacent 381 to the Changjiang (Yangtze) River estuary (1998-2001). Chinese Journal of Oceanology and 382 Limnology 27: 443-456. DOI: 10.1007/s00343-009-9155-6.

383 Zhang H, Xian WW and Liu SD. 2015. Ichthyoplankton assemblage structure of springs in the 384 Yangtze Estuary revealed by biological and environmental visions. PeerJ 3:e1186. DOI $385 \quad 10.7717 /$ peerj. 1186.

386 Zhou SQ, Shen ZL, Li Z, Yao Y. 2007. Distribution features of nutrients in the maximum turbid 387 zone of the Changjiang estuary and its adjacent sea areas. Marine Sciences 31(6):34-42. (in 388 Chinese with an English abstract)

389 Zhu XH, Liu D, Sha XK. 2002. Relationship between community structure of ichthyoplankton 390 and environmental factors in the Estuary of Changjiang River in spring. Studia Marina Sinica 391 5:169-179. (in Chinese with an English abstract) 


\section{1}

Fig. 1 Ichthyoplankton sampling stations in the Yangtze Estuary
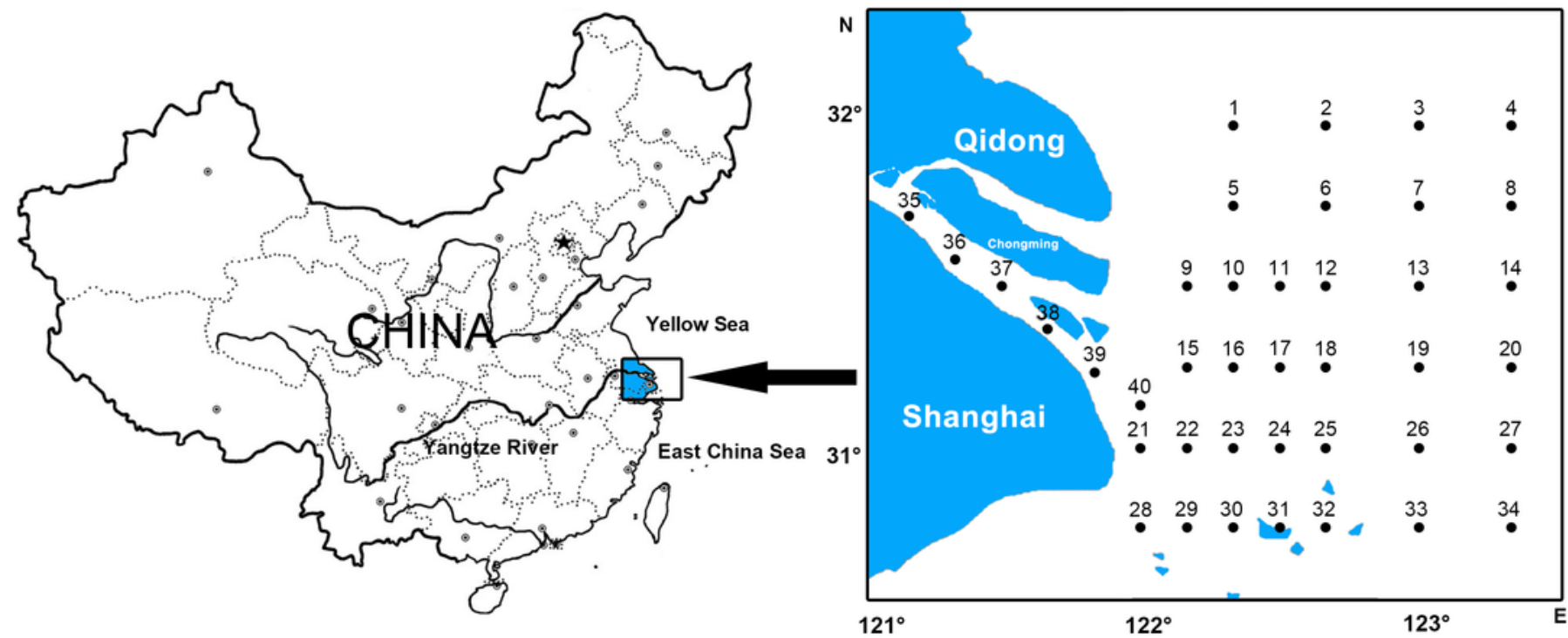


\section{Table $\mathbf{1}$ (on next page)}

Table 1 Ichthyoplankton species assemblage revealed by CCA in the Yangtze Estuary in the autumns 
Table 1 Ichthyoplankton species assemblage revealed by CCA in the Yangtze Estuary in the autumns

\begin{tabular}{|c|c|c|c|c|c|c|c|c|c|c|c|c|}
\hline \multirow[b]{2}{*}{ Species } & \multirow{2}{*}{$\begin{array}{c}\text { abbreviatio } \\
\mathrm{n}\end{array}$} & \multirow{2}{*}{$\begin{array}{c}\text { Species } \\
\text { assemblage }\end{array}$} & 199 & 200 & 200 & 200 & 200 & 200 & 200 & \multicolumn{3}{|c|}{ Percentage caught in station areas* } \\
\hline & & & 8 & 0 & 2 & 3 & 4 & 7 & 9 & $\begin{array}{c}\text { Estuary } \\
\text { area }\end{array}$ & $\begin{array}{c}\text { Coastal } \\
\text { area }\end{array}$ & $\begin{array}{c}\text { Offshore } \\
\text { area }\end{array}$ \\
\hline Hypoatherina valenciennei & Hval & - & & & & & & $\sqrt{ }$ & $\sqrt{ }$ & & & $0.65(2)$ \\
\hline Thryssa kammalensis & Tkam & + & & & & & & $\sqrt{ }$ & $\sqrt{ }$ & & $1.11(3)$ & $3.23(5)$ \\
\hline Larimichthys crocea & Lcro & + & & & $\sqrt{ }$ & & & & & & $0.56(2)$ & $3.23(6)$ \\
\hline Trichiurus lepturus & Tlep & + & & & $\sqrt{ }$ & & & & $\sqrt{ }$ & $0.39(1)$ & $1.67(3)$ & $58.71(18)$ \\
\hline Coilia nasus & Cnas & $x$ & & & & & & $\sqrt{ }$ & $\sqrt{ }$ & $0.39(1)$ & $0.84(3)$ & \\
\hline Sparidae sp. & Spar & - & & & & & $\sqrt{ }$ & & & & $0.28(1)$ & \\
\hline Pholis fangi & Pfan & - & & & $\sqrt{ }$ & & & & & & $0.28(1)$ & \\
\hline Coilia mystus & Cmys & x & $\sqrt{ }$ & & & & & $\sqrt{ }$ & & $0.79(1)$ & $2.79(4)$ & $0.32(1)$ \\
\hline Pseudolaubuca engraulis & Peng & $\Delta$ & & $\sqrt{ }$ & & & & & & $2.36(3)$ & & \\
\hline $\begin{array}{l}\text { Odontamblyopus } \\
\text { rubicundus }\end{array}$ & Orub & - & & & $\sqrt{ }$ & & & & & & $0.28(1)$ & \\
\hline Minous monodactylus & Mmon & - & & & & & & $\sqrt{ }$ & & & & $0.65(1)$ \\
\hline Saurida undosquamis & Sund & - & & & & & $\sqrt{ }$ & & & & $0.28(1)$ & \\
\hline Setipinna taty & Stat & - & & & & & & & $\sqrt{ }$ & & $0.28(1)$ & \\
\hline Syngnathus acus & Sacu & $x$ & & $\sqrt{ }$ & & & & $\sqrt{ }$ & $\sqrt{ }$ & & $3.62(6)$ & \\
\hline
\end{tabular}




\begin{tabular}{|c|c|c|c|c|c|c|c|c|c|c|c|c|}
\hline Stolephorus commersonnii & Scom & $x$ & $\sqrt{ }$ & $\sqrt{ }$ & & $\sqrt{ }$ & $\sqrt{ }$ & & & & $23.40(9)$ & $4.84(8)$ \\
\hline Harpadon nehereus & Hneh & + & & $\sqrt{ }$ & $\sqrt{ }$ & $\sqrt{ }$ & $\sqrt{ }$ & $\sqrt{ }$ & $\sqrt{ }$ & & $1.67(5)$ & $3.87(7)$ \\
\hline Lateolabrax japonicus & Ljap & + & & $\sqrt{ }$ & $\sqrt{ }$ & & & & & & & $2.90(5)$ \\
\hline Pseudorasbora parva & Ppar & $\Delta$ & $\sqrt{ }$ & & & & & & $\sqrt{ }$ & $11.42(6)$ & & \\
\hline Chaeturichthys stigmatias & Csti & $\Delta$ & & & & & & $\sqrt{ }$ & $\sqrt{ }$ & $57.48(3)$ & $2.51(2)$ & \\
\hline Omobranchus elegans & Oele & - & & & & & & & $\sqrt{ }$ & & & \\
\hline Benthosema pterotum & Bpte & + & & & $\sqrt{ }$ & & & $\sqrt{ }$ & & & $0.28(1)$ & $3.23(3)$ \\
\hline Channa asiatica & Casi & - & & $\sqrt{ }$ & $\sqrt{ }$ & & & & & & $0.28(1)$ & $1.29(4)$ \\
\hline Salanx prognathus & Spro & $\Delta$ & & & & & & $\sqrt{ }$ & & $22.05(1)$ & $29.81(6)$ & \\
\hline Stolephorus zollingeri & Szol & + & & & & $\sqrt{ }$ & & & & & & $0.65(2)$ \\
\hline Acentrogobius caninus & Acan & - & & $\sqrt{ }$ & & & & & & $0.39(1)$ & & \\
\hline Argyrosomus japonicus & Ajap & - & & $\sqrt{ }$ & & & & & & & & $0.32(1)$ \\
\hline Engraulis japonicus & Ejap & $x$ & & $\sqrt{ }$ & $\sqrt{ }$ & $\sqrt{ }$ & $\sqrt{ }$ & $\sqrt{ }$ & & & $20.06(8)$ & $10.65(10)$ \\
\hline Apogon lineatus & Alin & - & & & & & & $\sqrt{ }$ & & & & $0.65(1)$ \\
\hline Pseudolaubuca sinensis & $P \sin$ & - & & $\sqrt{ }$ & & & $\sqrt{ }$ & $\sqrt{ }$ & & $2.36(3)$ & & \\
\hline Salanx ariskensis & Sari & $x$ & & $\sqrt{ }$ & $\sqrt{ }$ & & $\sqrt{ }$ & & & $2.36(1)$ & $8.64(7)$ & $1.29(4)$ \\
\hline Hyporhamphus limbatus & Hlim & - & & & & & & & $\sqrt{ }$ & & & $0.97(1)$ \\
\hline Callionymidae sp. & Call & - & & & $\sqrt{ }$ & & & & & & & $0.32(1)$ \\
\hline species 1 & Spe1 & $x$ & & & $\sqrt{ }$ & & & $\sqrt{ }$ & & & & $2.26(2)$ \\
\hline
\end{tabular}

3 
$4 \quad$ Note: $\boldsymbol{\Delta}$ Estuary assemblage

5

X Coastal assemblage

6

+ Offshore assemblage

- Rare species determined by IRI, which were excluded for the species assemblage analysis

$\sqrt{ }$ The species was collected in the year

* Numbers in parentheses indicated the amounts of stations that the species was caught. 
2

CCA biplot of ichthyoplankton species in the Yangtze Estuary in the autumns




Table 2 (on next page)

Table 2 Dominant species determined by the IRI 
Table 2 Dominant species determined by the IRI

\begin{tabular}{|c|c|c|c|c|c|c|c|}
\hline \multirow[t]{2}{*}{ Species } & \multicolumn{7}{|c|}{ IRI } \\
\hline & 1998 & 2000 & 2002 & 2003 & 2004 & 2007 & 2009 \\
\hline Trichiurus lepturus & & & 807.10 & & & & 3145.50 \\
\hline Salanx prognathus & & & & & & 710.31 & \\
\hline Stolephorus commersonnii & 334.49 & 4.43 & & 1686.24 & 713.97 & & \\
\hline Engraulis japonicus & & 177.38 & 8.87 & 6.02 & 4.43 & 584.08 & \\
\hline Chaeturichthys stigmatias & & & & & & 329.48 & 1.05 \\
\hline Salanx ariskensis & & 345.90 & 53.22 & & 319.29 & & \\
\hline Pseudorasbora parva & 459.93 & & & & & & 22.08 \\
\hline Harpadon nehereus & & 124.17 & 26.61 & 3.01 & 4.43 & 6.42 & 42.05 \\
\hline Larimichthys crocea & & & 141.91 & & & & \\
\hline
\end{tabular}

2 
3

Fig. 3. CCA biplot of sampling stations for ichthyoplankton in the Yangtze Estuary in the autumns 

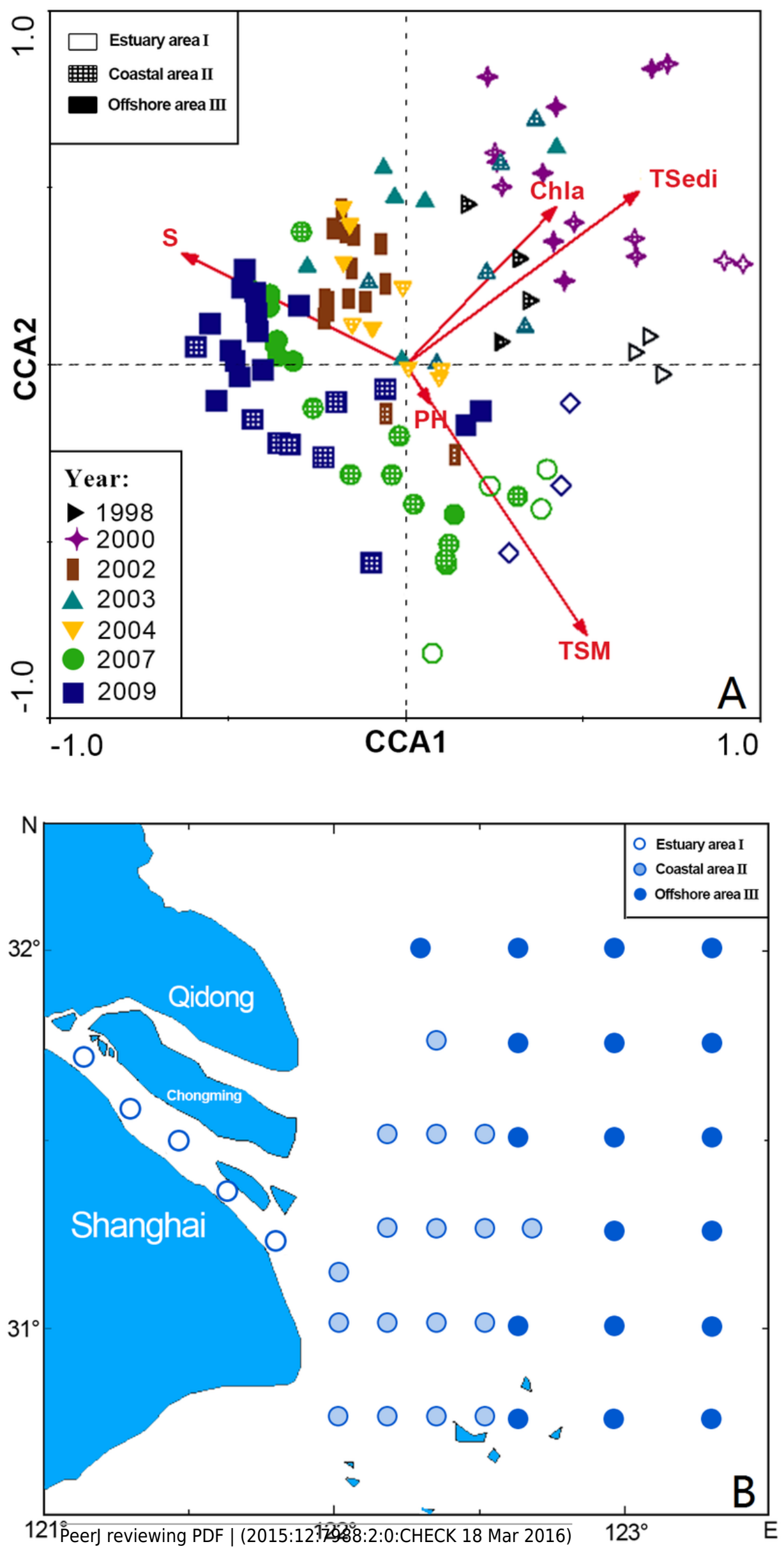


\section{Table 3(on next page)}

Table 3 Results of canonical correspondence analysis relating ichthyoplankton abundance data to environmental variables in the Yangtze Estuary in the autumns 
1 Table 3 Results of canonical correspondence analysis relating ichthyoplankton abundance data to 2 environmental variables in the Yangtze Estuary in the autumns

3

\begin{tabular}{|c|c|c|c|c|c|}
\hline & \multicolumn{4}{|c|}{ CCA axes } & \multirow{2}{*}{ Total inertia } \\
\hline & 1 & 2 & 3 & 4 & \\
\hline Eigenvalues & 0.696 & 0.549 & 0.419 & 0.389 & 11.741 \\
\hline Species-environment correlations & 0.884 & 0.788 & 0.680 & 0.689 & \\
\hline \multicolumn{6}{|l|}{ Cumulative percentage variance } \\
\hline of species data & 5.9 & 10.6 & 14.2 & 17.5 & \\
\hline of species-environment relation & 24.5 & 43.8 & 58.5 & 72.2 & \\
\hline Sum of all unconstrained eigenvalues & & & & & 11.741 \\
\hline Sum of all canonical eigenvalues & & & & & 2.844 \\
\hline
\end{tabular}

4

5 


\section{Table 4(on next page)}

Table 4 Conditional effects and correlations of environmental variables with the CCA axes 
1 Table 4 Conditional effects and correlations of environmental variables with the CCA axes

\begin{tabular}{cccccc}
\hline Environmental factors & LambdaA & P value & F value & Axis1 & Axis2 \\
\hline TSM & 0.49 & 0.002 & 4.8 & 0.53 & -0.44 \\
TSedi & 0.44 & 0.002 & 4.48 & 0.33 & 0.52 \\
S & 0.36 & 0.002 & 3.64 & -0.58 & 0.08 \\
Chla & 0.32 & 0.002 & 3.45 & 0.21 & 0.42 \\
PH & 0.31 & 0.01 & 3.27 & 0.05 & -0.06 \\
T & 0.21 & 0.056 & 2.28 & 0.16 & 0.11 \\
D & 0.17 & 0.058 & 1.94 & -0.61 & 0.19 \\
TP & 0.17 & 0.06 & 1.83 & 0.56 & -0.35 \\
Trans & 0.15 & 0.056 & 1.72 & -0.46 & 0.38 \\
TN & 0.12 & 0.186 & 1.38 & 0.54 & -0.17 \\
DO & 0.1 & 0.378 & 1.13 & 0.22 & -0.15 \\
\hline
\end{tabular}

2 